\title{
Job Cards in MGNREGS Registered: Based on Need or Caution: A Micro Level Analaysis
}

\author{
A. Santhappan \\ Ph. D. Research Scholar, Department of Lifelong Learning and \\ Extension Education, Gandhigram Rural Institute (Deemed University), \\ Gandhigram, Dindigul (Dt.), Tamil Nadu, India
}

\begin{abstract}
The flagship programme of the Indian Government MGNREGS - is aiming at enhancing the livelihood security of the rural households through guaranteed 100 days of manual wage employment in a fiscal year to its adult member, who is willing to do manual work. There is a registration process involved to obtain job cards for benefiting from this programme. Even though the process looks like simple steps, it involved time, labour and money of the intended beneficiaries to register and obtain the job cards. Insufficient clarity and understanding from the parts of both the implementers and beneficiaries, more people than the actual beneficiaries have registered and obtained job cards under this scheme, through which the implementers spent lot of time, energy and money on providing the job cards as well as keeping the data base. This article analyses the cause and effect of more number of registration and brings out some suggestions to avoid over burdening with more data and keep the beneficiaries with more clarity on the programme for effective participation.
\end{abstract}

Keywords: Mahatma Gandhi National Rural Employment Guarantee Scheme (MGNREGS), National Rural Employment Guarantee Act - 2005, Registration in MGNREGS, Non-registered Families, Registered Families, Participating Families, Job Cards, Livelihood

\section{INTRODUCTION}

'Mahatma Gandhi National Rural Employment Guarantee Scheme' (MGNREGS) is the flagship programme of the Government of India, which is implemented based on the Act of Legislation in the Indian Parliament in the year 2005 as 'National Rural Employment Guarantee Act - 2005' (NREGA 2005) for the rural mass towards enhancing their livelihood security by providing 100 man days of guaranteed manual work against daily wage to one of the willing adult members in each of the family. NREGA - 2005 was put into action as 'National Rural Employment Guarantee Act Scheme' from the year 2006. This scheme aspires to enhance the livelihood security of the Indian rural mass through involving the workforce involving in constructing new and renovating and maintain existing physical and natural capitals of the community. This scheme was named as 'Mahatma Gandhi National Rural Employment Guarantee Scheme' in 2009 to indicate the importance of this programme.

There is a huge difference in the number of rural families live in the hamlet, registered under this MGNREGS and taking part in the programme. All the families that are living in the rural areas have not registered in MGNREGS and all the families that are registered in MGNREGS have not taken part in the programme. There are many reasons for not registering, registering but not participating at all, registering but taking part for namesake and registering and taking part in this programme. There 
may be or may not be genuine reasons from the side of the beneficiaries for such action. But, keeping and administrating data base of all the registered families is a heavy burden on the part of the service provider, i.e., Government of India. And also, the behavioural pattern of the rural people indicates 'something' to the implementers, which should be taken into the account. This difference in number of non-registered families vs. registered families vs. participating families in the programme has become the background of this article for probing and discussing the reasons that why all the families that are living in the rural areas have not registered under MGNREGS, why all the families that are registered in MGNREGS have not taking part in the programme and why only the participating families continue to take part in this programme. And also, it tries to recommend and suggest the ways to facilitate the families that need this programme as this is the only livelihood option or this is one of the livelihood options to register their name under this programme.

\section{REGISTERING AND OBTAINING JOB CARD IN MGNREGS}

All the government programmes have defined and specific target group or groups. It is the procedure that the beneficiary should provide necessary identity proof or necessary certificate from the competent authority to ensure the participant as a genuine case and benefit from the specific programme or scheme of the government. As in any other government programme, registering and obtaining job card in MGNREGS is a process carried out by the respective panchayat to ensure the identity of the beneficiary and permit the beneficiary to take part in the programme. As per the National Rural Employment Guarantee Act - 2005 (NREGA - 2005), the criterion of the beneficiary of MGNREGS is that the adult members of the families that are living in rural panchayat limit can register under this programme as beneficiaries of this programme; all the adult members in a family can register and obtain job card; but, they will be considered as one 'beneficiary family', which is entitled to gain a wage employment of 100 days in a fiscal year. Following is the present process followed for registering and obtaining job card in MGNREGS:
The prerequisite condition to register in MGNREGS is that the willing adult member should have a Savings Bank Account in the local or neighbouring bank (normally, the bank is nominated by the local panchayat for administrative and transaction purposes);

The willing adult member should fill the prescribed application form, which is available in the respective panchayat office, and submit it in the same office along with the identity proves / certificates, like, Ration Card, Aadhaar Card, etc. (now, Aadhaar Card has become mandatory one for registration), copy of the bank pass book first page, where photo, name, address and account number of the customer are placed along with the bank branch details and four copies of passport size photos for registration.

After verifying all the details provided by the applicant, the panchayat issues the Job Card to the applicant in another 15 days from the date of submission of his / her completed application.

The cover page of the Job Card bears the details of the beneficiary, such as name, parent or spouse name, complete address, photo, along with scheme name, serial number of the family and a code of English alphabet, like, $\mathrm{A}$ or $\mathrm{B}$ or $\mathrm{C}$ or $\mathrm{D}$, etc., for the individual adult member along with the seal and signature of the competent authority - Panchayat Board President or Special Officer of the Panchayat Union / Block (when the Panchayat Board President is absent). There are printed leaves of papers inside the cover to take attendance on each of the work day the beneficiary worked in each of the month in a fiscal year. The serial number in the cover page contains twelve digits and one alphabet at the end; first eight digits stand as codes to indicate the respective state (first and second digits), respective district in the state (third and fourth digits), respective block / union in the district (fifth and sixth digits) and respective panchayat in the block / union (seventh and eighth) and the last four digits indicating the serial number of the family in the respective panchayat under this scheme. The final English alphabet denotes the respective person in the family. 
For example, a job card bearing the number '292602160353 B' indicates that:

\begin{tabular}{|c|c|c|c|c|c|}
\hline State & District & $\begin{array}{c}\text { Block / } \\
\text { Panchayat } \\
\text { Union }\end{array}$ & Village Panchayat & $\begin{array}{c}\text { Family } \\
\text { registered in } \\
\text { the scheme }\end{array}$ & $\begin{array}{c}\text { Individual's } \\
\text { name }\end{array}$ \\
\hline Tamil Nadu & Tirunelveli & Manur & Seethaparpanallur & Serial Number & Mrs. Gowri \\
\hline 29 & 26 & 02 & 16 & 0353 & B \\
\hline
\end{tabular}

This is a highly systematised way of coding the beneficiaries of a programme. Through this number allotment, one panchayat can issue the job cards up to a total number of 9999 families continuously without altering the serial number. By using this Job Card number, one can find out the details of any beneficiary through online search in the website of Ministry for Rural Development and Panchyat Raj, Government of India. Since all the work details of each beneficiary are digitalised throughout India, the needed person can view either the progress of each project or share of each beneficiary in terms of man days worked and finance involved.

\section{THE ASSUMPTIONS BEHIND REGISTRATION OF MGNREGS}

Most of the programmes that are implemented in India had not been supported by the beneficiaries properly. This was because of the insufficient communication between and or the unequal understanding between the implementers and the beneficiaries on the programme. The implementers of the MGNREGS - the Government of India systematically launched the programme: Enactment of Legislation, defining the beneficiaries and the projects, setting up the timeframe, the implementing agency, the hierarchy, the officials and office incharge and the funds and other provisions and setting up the grievance mechanism. The people in rural India were also informed through popular media and official channels. The implementers are content with the way they communicated; and, they never tested back about their communication whether it has reached sufficiently or not to the beneficiaries' level and to their understanding. This one-way communication also led the implementers to assume that people are sufficiently informed and the people to assume that many things are going to happen from the government side.

A study conducted among all the participants of the programme from two panchayats, namely, Seethaparpanallur panchayat in Manur Panchayat Union, Sivasailabm panchayat in Kadayam Panchayat Union, of Tirunelveli District, who participated during the fiscal years 2013 - 14 and $2014-2015$, to assess the impact of MGNREGS on enhancement of the rural livelihood revealed that the beneficiaries had got the information about the programme through the informal and non-formal communication methods.

\subsection{MEANS OF COMMUNICATION}

Government used newspapers, magazines and Televisions to propagate the information on launching of the programme - MGNREGS. And also, it asked the Panchyat Raj Institutions to inform the people about launching of this programme. Panchayat Raj Institutions had used one meeting of Grama Sabha for this purpose. But, the above said study revealed that none of the participants of the programme took part in the Gram Sabha meetings. 
International Journal of Trend in Scientific Research and Development (IJTSRD) ISSN: 2456-6470

TABLE - 1 SEX WISE DISTRIBUTION OF RESPONDENTS: PANCHAYAT WISE AND IN TOTAL

\begin{tabular}{|c|c|c|c|c|c|c|c|}
\hline \multirow{3}{*}{$\begin{array}{l}\text { S. No. } \\
1 .\end{array}$} & \multirow{3}{*}{$\begin{array}{c}\text { Hamlet } \\
\text { Seethaparpanallur Panchayat }\end{array}$} & \multicolumn{6}{|c|}{ Respondents } \\
\hline & & \multicolumn{2}{|c|}{ Male } & \multicolumn{2}{|c|}{ Female } & \multicolumn{2}{|c|}{ Total } \\
\hline & & No. & $\begin{array}{l}\text { per } \\
\text { cent }\end{array}$ & No. & $\begin{array}{l}\text { per } \\
\text { cent }\end{array}$ & No. & $\begin{array}{c}\text { per } \\
\text { cent }\end{array}$ \\
\hline 1.1. & Kangeyankulam & 0 & 0 & 27 & 7.69 & 34 & 9.69 \\
\hline 1. 2. & Karuvanallur & 7 & 1.99 & 42 & 11.97 & 49 & 13.96 \\
\hline 1.3. & Seethaparpanallur & 7 & 1.99 & 78 & 22.22 & 95 & 27.07 \\
\hline 1.4. & Sirukkankurichi & 17 & 4.84 & 105 & 29.91 & 109 & 31.05 \\
\hline \multirow[t]{2}{*}{1.5 . } & Velarkulam & 4 & 1.14 & 64 & 18.23 & 99 & 28.21 \\
\hline & Total - 1 & 35 & 9.97 & 316 & 90.03 & 351 & 100.00 \\
\hline 2. & Sivasailam Panchayat & & & & & & \\
\hline 2. 1 . & Karuththappillaiyur & 10 & 6.10 & 80 & 48.78 & 90 & 54.88 \\
\hline 2. 2 . & P. P. Kudiyiruppu & 1 & 0.61 & 38 & 23.17 & 39 & 23.78 \\
\hline 3.3. & Puthukkudiyiruppu & 14 & 8.54 & 2 & 1.22 & 16 & 9.76 \\
\hline \multirow[t]{3}{*}{2.4.} & Sivasailam & 3 & 1.83 & 16 & 9.76 & 19 & 11.59 \\
\hline & Total - 2 & 28 & 17.07 & 136 & 82.93 & 164 & 100.00 \\
\hline & Grand Total & 63 & 13.52 & 452 & 86.48 & 515 & 100.00 \\
\hline
\end{tabular}

Source: Computed from field data; Data presented in parentheses are percentage.

The above table (Table - 1) shows that the women participation is very much higher than their counterpart, in Seethaparpanallur (90 per cent) and Sivasailam (82.93 per cent) Panchayts in MGNREGS programme. Neither the male nor the female participants participated in the Gram Sabha meetings from both the panchayats. The reason is that neither the implementers nor the participants realised the real power of PRI, its decision making process and its power. Therefore, the people are given low priority in taking part in the meeting. In Indian society, generally, women are given low status than men. When there is no male participant of the programme takes part in the Gram Sabha meeting, how one can expect the female participant of the programme to take part in it.

\section{TABLE - 2 EDUCATIONAL BACKGROUND OF THE RESPONDENTS}

\begin{tabular}{|c|c|c|c|c|c|c|c|}
\hline \multirow{3}{*}{$\begin{array}{l}\text { S. No. } \\
1 .\end{array}$} & \multirow{3}{*}{\begin{tabular}{|c|} 
Level of Education \\
Seethaparpanallur Panchayat
\end{tabular}} & \multicolumn{6}{|c|}{ Respondents } \\
\hline & & \multicolumn{2}{|c|}{ Male } & \multicolumn{2}{|c|}{ Female } & \multicolumn{2}{|c|}{ Total } \\
\hline & & No. & per cent & No. & per cent & No. & per cent \\
\hline 1. 1. & Not attended schooling & 5 & 1.42 & 155 & 44.16 & 160 & 45.58 \\
\hline 1. 2. & Primary & 10 & 2.85 & 105 & 29.91 & 115 & 32.76 \\
\hline 1. 3. & Middle & 17 & 4.84 & 43 & 12.25 & 60 & 17.09 \\
\hline 1.4. & High & 3 & 0.85 & 10 & 2.85 & 13 & 3.70 \\
\hline 1.5 . & Higher Secondary & 0 & 0.00 & 3 & 0.85 & 3 & 0.85 \\
\hline 1.6. & Higher Education & 0 & 0.00 & 0 & 0.00 & 0 & 0.00 \\
\hline & Total - 1 & 35 & 9.97 & 316 & 90.03 & 351 & 100.00 \\
\hline
\end{tabular}


International Journal of Trend in Scientific Research and Development (IJTSRD) ISSN: 2456-6470

\begin{tabular}{|c|c|c|c|c|c|c|c|}
\hline 2. & Sivasailam Panchayat & & & & & & \\
\hline 2. 1. & Not attended schooling & 3 & 1.83 & 63 & 38.41 & 66 & 40.24 \\
\hline 2. 2 . & Primary & 15 & 9.15 & 56 & 34.15 & 71 & 43.29 \\
\hline 2.3. & Middle & 8 & 4.88 & 12 & 7.32 & 20 & 12.20 \\
\hline 2.4. & High & 1 & 0.61 & 4 & 2.44 & 5 & 3.05 \\
\hline 2. 5 . & Higher Secondary & 0 & 0.00 & 1 & 0.61 & 1 & 0.61 \\
\hline \multirow[t]{2}{*}{2.6.} & Higher Education & 1 & 0.61 & 0 & 0.00 & 1 & 0.61 \\
\hline & Total -2 & 28 & 17.07 & 136 & 82.93 & 164 & 100.00 \\
\hline 3. & Total of both the panchayats & & & & & & \\
\hline 3.1. & Not attended schooling & 8 & 1.55 & 218 & 42.33 & 226 & 43.88 \\
\hline 3.2 . & Primary & 25 & 4.85 & 161 & 31.26 & 186 & 36.12 \\
\hline 3.3. & Middle & 25 & 4.85 & 55 & 10.68 & 80 & 15.53 \\
\hline 3.4. & High & 4 & 0.78 & 14 & 2.72 & 18 & 3.50 \\
\hline 3.5. & Higher Secondary & 0 & 0.00 & 4 & 0.78 & 4 & 0.78 \\
\hline \multirow[t]{2}{*}{3.6.} & Higher Education & 1 & 0.19 & 0 & 0.00 & 1 & 0.19 \\
\hline & Grand Total & 63 & 12.23 & 452 & 87.77 & 515 & 100.00 \\
\hline
\end{tabular}

Source: Computed from field data; Data presented in parentheses are percentage.

The above table (Table - 2) shows that the people with no or less qualification in formal education (not attended the school or primary level of education) participate more in number (80 per cent) in this programme. As education level increases, the number of participants decreases, which indicates that the MGNREGS programme functions only as unskilled and mere manual labour programme as it is prescribed in the legislation. People in the rural areas, specially, illiterates and less literates, have their own methods, ways and times of communication. They use these methods, ways and times to pass on and receive messages. The organized sector - Government should have identified and used these methods, ways and times to send and receive communications with the rural mass, specially, illiterates and less literates.

\subsection{ONE-WAY COMMUNICATION}

Government had used almost all the formal ways of communication with communicating with the rural mass. For example, it had flashed the launch of the programme through newspapers, magazines and Televisions, which are formal and one-way communication media. And also, it used Gram Sabha meeting, which is another formal way of communication, where illiterates and less literates hardly take part. Moreover, these meetings are also one-way communication in most of the Gram Sabhas, where there is no discussion and only decision on matters takes place.

The inadequacy and insufficient clarity of communication kept the rural people in 'guessing' than 'understanding' the programme. This has manifested in registering and obtaining job cards in MGNREGS.

\section{MGNREGS JOB CARDS REGISTRATION: BASED ON NEED OR CAUTION}

The difference in number of households living in a hamlet, number of families registered in the MGNREGS programme and the number of households taking part in the programme is very vast. The time, money and energy spent by each and every family for registering in MGNREGS at all India level are a huge amount. But, these things had not bothered the implementers. Analysing the total number of households, number of registered households and number of participating households of the study area will come in help of understanding the situation much 
International Journal of Trend in Scientific Research and Development (IJTSRD) ISSN: 2456-6470

clear. The respondents of the study are from nine

hamlets of two village panchayats.

TABLE - 3

\section{DETAILS OF HAMLET WISE TOTAL HOUSEHOLDS AND HOUSEHOLDS REGISTERED AND ACTIVE IN MGNREGS OF STUDY PANCHAYATS}

\begin{tabular}{|c|c|c|c|c|c|c|c|}
\hline \multirow{3}{*}{$\begin{array}{l}\text { S. } \\
\text { No. }\end{array}$} & \multirow{3}{*}{$\begin{array}{l}\text { Panchayat wise } \\
\text { hamlet }\end{array}$} & \multicolumn{6}{|c|}{ Households } \\
\hline & & \multicolumn{2}{|c|}{ Total } & \multicolumn{2}{|c|}{$\begin{array}{l}\text { Registered in } \\
\text { MGNREGS }\end{array}$} & \multicolumn{2}{|c|}{$\begin{array}{c}\text { Active in } \\
\text { MGNREGS }\end{array}$} \\
\hline & & No. & per cent & No. & per cent & No. & per cent \\
\hline & Seethaparpanallur & & & & & & \\
\hline 1. & Kangeyankulam & 72 & 100 & 43 & 59.72 & 27 & 37.50 \\
\hline 2. & Karuvanallur & 145 & 100 & 127 & 87.59 & 49 & 33.79 \\
\hline 3. & Seethaparpanallur & 415 & 100 & 232 & 55.90 & 85 & 20.48 \\
\hline 4. & Sirukkankurichi & 308 & 100 & 182 & 59.09 & 122 & 39.61 \\
\hline \multirow[t]{3}{*}{5.} & Velarkulam & 142 & 100 & 110 & 77.46 & 68 & 47.89 \\
\hline & Total & 1082 & 100 & 694 & 64.14 & 351 & 32.44 \\
\hline & Sivasailam & & & & & & \\
\hline 1. & Karuththappillaiyur & 120 & 100 & 107 & 89.17 & 90 & 75.00 \\
\hline 2. & $\begin{array}{l}\text { Pethan Pillai } \\
\text { Kudiyiruppu }\end{array}$ & 140 & 100 & 119 & 85.00 & 39 & 27.86 \\
\hline 3. & Puthukkudiyiruppu & 122 & 100 & 91 & 74.59 & 16 & 13.11 \\
\hline 4. & Ramanathapuram & 23 & 100 & 7 & 30.43 & O & 0 \\
\hline \multirow[t]{3}{*}{5.} & Sivasailam & 74 & 100 & 60 & 81.08 & 19 & 25.68 \\
\hline & Total & 479 & 100 & 384 & 80.17 & 164 & 34.24 \\
\hline & Grand Total & 1561 & 100 & 1078 & 69.06 & 515 & 32.99 \\
\hline
\end{tabular}

The above table (Table - 3) shows the total number of household in the study panchayats and the distribution of MGNEGS's registered as well as participating households. (A hamlet called Ramanathapuram in Sivasailam panchayat has 23 households, which are belonging to SC (Arunthathiyar). Almost all of them are employed in menial jobs, like, sweeping, in the Panchayat and only seven households have registered and taking part in this programme. Since none of the seven households took part in the programme during both the years $(2013-2014 \& 2014-2015)$, they were not included in this study.)

An average of 32.99 per cent of rural households from these study panchayats is taking part in the programme, which indicates that around one out of two of the rural families have shown interest in taking part in the programme.
Out of the total households in Seethaparpanallur panchayat, 35.86 per cent have not registered, 64.14 per cent registered and 32.44 per cent takes part in the programme; whereas, in Sivasailam panchayat, 19.83 per cent have not registered, 80.17 per cent registered and 34.24 per cent takes part in the programme. In total, 30.94 have not registered, 69.06 per cent have registered and 32.99 per cent takes part in the programme from the study panchayats. The important thing to be noted is that 31.70 per cent from Seethaparpanallur panchayat, 45.93 per cent from Sivasailam panchayat and 36.07 per cent from the total households have registered in the programme but, not taking part in the programme. When we calculate it to the per cent of the registered households, 50.58 per cent from Seethaparpanallur panchayat, 42.71 per cent from Sivasailam panchayat and 47.77 per cent from both the panchayats have 
International Journal of Trend in Scientific Research and Development (IJTSRD) ISSN: 2456-6470

wasted their time, money and energy on just registering in MGNREGS. The need was for only actual need are, further, less than this. The following 52.33 per cent of the registered families. Even among these 52.33 per cent households, the households with

table (Table -4$)$ gives the details of it.

\section{TABLE - 4 ANNUAL MAN DAYS WORKED IN MGNREGS IN THE YEAR 2013 - 14}

\begin{tabular}{|c|c|c|c|c|c|c|c|c|c|}
\hline \multirow[b]{2}{*}{$\begin{array}{c}\text { S. } \\
\text { No. }\end{array}$} & \multirow[b]{2}{*}{ No. of days } & \multicolumn{2}{|c|}{ Seethaparpanallur } & \multicolumn{2}{|c|}{ Sivasailam } & \multicolumn{2}{|c|}{ Total } & \multicolumn{2}{|c|}{ Total (Combined) } \\
\hline & & No. & percent & No. & $\begin{array}{c}\text { per } \\
\text { cent }\end{array}$ & No. & $\begin{array}{c}\text { per } \\
\text { cent }\end{array}$ & No. & $\begin{array}{c}\text { per } \\
\text { cent }\end{array}$ \\
\hline 1. & 01 - 10 days & 24 & 6.84 & 6 & 3.66 & 30 & 5.83 & \multirow{3}{*}{86} & \multirow{3}{*}{16.70} \\
\hline 2. & 11 - 20 days & 17 & 4.84 & 7 & 4.27 & 24 & 4.66 & & \\
\hline 3. & 21 - 30 days & 19 & 5.41 & 13 & 7.93 & 32 & 6.21 & & \\
\hline 4. & 31 - 40 days & 20 & 5.70 & 7 & 4.27 & 27 & 5.24 & \multirow{3}{*}{83} & \multirow{3}{*}{16.12} \\
\hline 5. & 41 - 50 days & 17 & 4.84 & 12 & 7.32 & 29 & 5.63 & & \\
\hline 6. & $51-60$ days & 17 & 4.84 & 10 & 6.10 & 27 & 5.24 & & \\
\hline 7. & $61-70$ days & 12 & 3.42 & 10 & 6.10 & 22 & 4.27 & \multirow{3}{*}{139} & \multirow{3}{*}{26.99} \\
\hline 8. & 71 - 80 days & 35 & 9.97 & 14 & 8.54 & 49 & 9.51 & & \\
\hline 9. & 81 - 90 days & 50 & 14.25 & 18 & 10.98 & 68 & 13.20 & & \\
\hline 10. & $91-100$ days & 140 & 39.89 & 67 & 40.85 & 207 & 40.19 & 207 & 40.19 \\
\hline & Total & 351 & 100.00 & 164 & 100.00 & 515 & 100.00 & 515 & 100.00 \\
\hline
\end{tabular}

Source: Computed data from the Job Cards of the respondents; Data presented in parentheses are percentage.

The above table (Table - 4) shows that the number man days utilized by each participant family of MGNREGS during the year 2013 - 2014 accounting year. Due to various reasons, majority of the participant families, 59.81 per cent, have not utilised the opportunity of 100 days of employment completely. A total of 16.70 per cent participants worked from 1 to 30 days, 16.12 per cent of participants worked from 31 to 60 days, 26.99 per cent of participants worked from 61 to 90 days and 40.19 per cent participants worked from 91 to 100 days in the programme.

A total of 40.19 per cent of the participants have taken this MGNREGS completely as one of their livelihood option by utilizing 91 to 100 days, i.e., these participants were in need of one more livelihood option in the past to run their life. A total of 26.99 per cent of the participants are taking the programme as one more livelihood option, i.e., their past livelihood options are not robust to run their life; therefore, they are switching over from one or more livelihood options to this MGNREGS programme. For example, it was brought out in the focused group discussion that the Beedi works is not as it was some years before. Since there is high fluctuation in work days in the recent years, many started giving up Beedi works from their livelihood option. Another 16.12 per cent of the participants are just utilising this opportunity along with existing livelihood options, when they are free. But, another 16.70 per cent of the participants are unable to make it as one among their livelihood options. There may be valid reasons also, like, death, maternity, sickness and so on in their family, for this; but, most of this participants may not be in need of or unable to make use of this programme as their livelihood option.

Few points that had come out in the focused group discussion are important to note here. The participants, who utilise this programme least, are of the opinion that the government may cancel their family ration card (for receiving Civil Supplies) for not registering in and utilising this programme and they would be considered as families living above poverty line. And also, they are of the fear that they could be left out of any government free schemes in future, if they do not register and keep their Job Cards active. These types of fear also motivate the people to get registered under this programme and keep their job cards active by utilising it least. 
Therefore, it could be understood that more than 50 per cent of the households registered in MGNREGS are not in need of this programme at present in these panchayats. Their actual need is something else than taking part in this programme. They have registered their name and obtained job card based on their own understanding about this programme. They should be clarified on this matter in order to avoid further complications in both administration and field. The minimum needed time and money that a person has to spend in registering and obtaining a job card in Seethaparpanallur panchayat is given in Table -5 :

\section{TABLE - 5}

\section{COST PER PARTICIPANT FOR REGISTERING AND OBTAINIG JOB CARD IN MGNREGS}

\begin{tabular}{|l|l|r|}
\hline S. No. & \multicolumn{1}{|c|}{ Particulars } & $\begin{array}{c}\text { Amount in } \\
\text { Rupees }\end{array}$ \\
\hline 1. & Bank Account Opening & 750 \\
\hline 1.1. & Three days (daily wage labour cost) Rs. 250 x 3 days & 80 \\
\hline 1.2. & Pass port size photos & 10 \\
\hline 1.3. & Other proves / Photostat copying & 78 \\
\hline 1.4. & Travel & 750 \\
\hline 2. & Filing Application and obtaining Job Card - panchayat office & 100 \\
\hline 2.1. & Three days (daily wage labour cost) Rs. 250 x 3 days & 16 \\
\hline 2.2. & Pass port size photos with super imposed serial number & 26 \\
\hline 2.3. & Other proves / Photostat copying & $\mathbf{1 8 1 0}$ \\
\hline 2.4. & Travel to the photo studio & \\
\hline & Total &
\end{tabular}

Source: Direct interview with the beneficiaries in the year $2015-2016$.

The above table (Table - 5) shows that even to register and start taking part in this programme, a beneficiary has to spend six days of labour and a minimum of Rs. 310 cash for obtaining the job card. If it is calculated for the unutilised registrations in Seethaparpanallur panchayat alone, a total of 2058 man days and the cash of Rs. 106,330 had been spent on 343 job cards. If the man days are also worked out in cash, then it goes to the worth of Rs. 620,830. This is only from the part of the participants. In the administration part, the amount of organising part, like, the clerical work load, printing of job cards, ledgers, books and forms, filing of papers, maintaining of records and data base, etc., will cost the government equal to or more than this.

The following table (Table -6 ) gives the details of the years, when the respondents registered themselves in MGNREGS programme, obtained job card and started participating in the programme. About 54 per cent of the participants enrolled in the first two years of the programme, i.e., 2007 and 2008. Again, there was an increase in enrolment of participants in the programme, i.e., 26 per cent in the year 2012. The respondents explained the reason as an administrative one. There was a control in enrollment of the participants after two years from the starting of the programme. People also gave low priority to it since they were not very sure about the future of the programme. It was brought out in the focused group discussion that they were not aware about the complete programme. They have also mentioned that a government programme gets changed or stopped, when a new government is formed by another political party; therefore, they were reluctant to join in the programme at the beginning. They did not know that it is a Central Government programme, which is implemented through State Governments, based on a legal right.

They showed interest in enrollment, when a new state government was formed in 2011 and the programme was continued with a wage revision - increased wage. Therefore, there was a rise in the enrollment again in 2012. It indicates that the people were not informed and made educated about the complete programme to 
International Journal of Trend in Scientific Research and Development (IJTSRD) ISSN: 2456-6470

the needed level by which they develop confidence in the programme and participate in it with full involvement. And also, it indicates that there is a greater need for well informing and educating the people about the programme in which the people are a part and they should not be kept apart.

A livelihood option should create confidence in people, who opted for it. They should feel comfortable in utilising the option as one of their livelihood. But, in MGNREGS, people have misunderstood this programme and they tried to take shelter under this, which have expended a considerable amount of cost from both the side of people as well as from the administration - Central and State Governments.

\section{TABLE - 6 YEAR OF ENROLMENT IN MGNREGS AND JOB CARD RECEIVED}

\begin{tabular}{|c|c|c|c|c|c|c|c|c|c|c|c|c|c|c|c|c|c|c|c|}
\hline \multirow{3}{*}{$\begin{array}{c}\text { S. } \\
\text { No. }\end{array}$} & \multirow{3}{*}{$\begin{array}{l}\text { Ye } \\
\text { ar }\end{array}$} & \multicolumn{6}{|c|}{ Seethaparpanallur Panchayat } & \multicolumn{6}{|c|}{ Sivasailam Panchayat } & \multicolumn{6}{|c|}{ Total } \\
\hline & & \multicolumn{2}{|c|}{ Male } & \multicolumn{2}{|c|}{ Female } & \multicolumn{2}{|c|}{ Total } & \multicolumn{2}{|c|}{ Male } & \multicolumn{2}{|c|}{ Female } & \multicolumn{2}{|c|}{ Total } & \multicolumn{2}{|c|}{ Male } & \multicolumn{2}{|c|}{ Female } & \multicolumn{2}{|c|}{ Total } \\
\hline & & $\begin{array}{l}\mathbf{N} \\
\text { o. }\end{array}$ & $\begin{array}{l}\text { per } \\
\text { cent }\end{array}$ & $\begin{array}{l}\mathbf{N} \\
\text { o. }\end{array}$ & $\begin{array}{l}\text { per } \\
\text { cent }\end{array}$ & $\begin{array}{l}\mathbf{N} \\
\text { o. }\end{array}$ & $\begin{array}{l}\text { per } \\
\text { cent }\end{array}$ & $\begin{array}{l}\mathbf{N} \\
\text { o. }\end{array}$ & $\begin{array}{c}\text { per } \\
\text { cen } \\
\mathbf{t}\end{array}$ & $\begin{array}{l}\mathbf{N} \\
\text { o. }\end{array}$ & $\begin{array}{c}\text { per } \\
\text { cen } \\
\mathbf{t}\end{array}$ & $\begin{array}{l}\mathbf{N} \\
\text { o. }\end{array}$ & $\begin{array}{c}\text { per } \\
\text { cen } \\
t\end{array}$ & $\begin{array}{l}\mathbf{N} \\
\text { o. }\end{array}$ & $\begin{array}{c}\text { per } \\
\text { cen } \\
\mathbf{t}\end{array}$ & $\begin{array}{l}\mathbf{N} \\
\text { o. }\end{array}$ & $\begin{array}{c}\text { per } \\
\text { cen } \\
\mathbf{t}\end{array}$ & $\begin{array}{l}\mathbf{N} \\
\text { o. }\end{array}$ & $\begin{array}{c}\text { per } \\
\text { cen } \\
\mathbf{t}\end{array}$ \\
\hline 1. & $\begin{array}{l}20 \\
07\end{array}$ & $\begin{array}{l}1 \\
2\end{array}$ & 3.42 & $\begin{array}{l}8 \\
7\end{array}$ & $\begin{array}{r}24.7 \\
9\end{array}$ & $\begin{array}{l}9 \\
9\end{array}$ & $\begin{array}{r}28.2 \\
1\end{array}$ & $\begin{array}{l}1 \\
6\end{array}$ & $\begin{array}{r}9.7 \\
6\end{array}$ & $\begin{array}{l}8 \\
2\end{array}$ & $\begin{array}{r}50 \\
00\end{array}$ & $\begin{array}{l}9 \\
8\end{array}$ & $\begin{array}{r}59.7 \\
6\end{array}$ & $\begin{array}{l}2 \\
8\end{array}$ & $\begin{array}{r}5.4 \\
4\end{array}$ & $\begin{array}{l}1 \\
6 \\
9\end{array}$ & $\begin{array}{r}32 . \\
82\end{array}$ & $\begin{array}{l}1 \\
9 \\
7\end{array}$ & 38 \\
\hline 2. & $\begin{array}{l}20 \\
08\end{array}$ & $\begin{array}{l}1 \\
0\end{array}$ & 2.85 & $\begin{array}{l}6 \\
9\end{array}$ & $\begin{array}{r}19.6 \\
6\end{array}$ & $\begin{array}{l}7 \\
9\end{array}$ & $\begin{array}{r}22.5 \\
1\end{array}$ & 1 & $\begin{array}{r}0.6 \\
1\end{array}$ & 3 & $\begin{array}{r}1.8 \\
3\end{array}$ & 4 & 2.44 & $\begin{array}{l}1 \\
1\end{array}$ & $\begin{array}{r}2.1 \\
4\end{array}$ & $\begin{array}{l}7 \\
2\end{array}$ & $\begin{array}{r}13 . \\
98\end{array}$ & $\begin{array}{l}8 \\
3\end{array}$ & 16 \\
\hline 3. & $\begin{array}{l}20 \\
09\end{array}$ & 1 & 0.28 & 7 & 1.99 & 8 & 2.28 & 1 & $\begin{array}{r}0.6 \\
1\end{array}$ & 1 & $\begin{array}{r}0.6 \\
1\end{array}$ & 2 & 1.22 & 2 & $\begin{array}{r}0.3 \\
9\end{array}$ & 8 & $\begin{array}{r}1.5 \\
5\end{array}$ & $\begin{array}{l}1 \\
0\end{array}$ & 2 \\
\hline 4. & $\begin{array}{l}20 \\
10\end{array}$ & 2 & 0.57 & $\begin{array}{l}3 \\
5\end{array}$ & 9.97 & $\begin{array}{l}3 \\
7\end{array}$ & $\begin{array}{r}10.5 \\
4\end{array}$ & 1 & $\begin{array}{r}0.6 \\
1\end{array}$ & 5 & $\begin{array}{r}3.0 \\
5\end{array}$ & 6 & 3.66 & 3 & $\begin{array}{r}0.5 \\
8\end{array}$ & $\begin{array}{l}4 \\
0\end{array}$ & $\begin{array}{r}7.7 \\
7\end{array}$ & $\begin{array}{l}4 \\
3\end{array}$ & 8 \\
\hline 5. & $\begin{array}{l}20 \\
11\end{array}$ & 1 & 0.28 & $\begin{array}{l}2 \\
4\end{array}$ & 6.84 & $\begin{array}{l}2 \\
5\end{array}$ & 7.12 & 1 & $\begin{array}{r}0.6 \\
1\end{array}$ & 3 & $\begin{array}{r}1.8 \\
3\end{array}$ & 4 & 2.44 & 2 & $\begin{array}{r}0.3 \\
9\end{array}$ & $\begin{array}{l}2 \\
7\end{array}$ & $\begin{array}{r}5.2 \\
4\end{array}$ & $\begin{array}{l}2 \\
9\end{array}$ & 6 \\
\hline 6. & $\begin{array}{l}20 \\
12\end{array}$ & 8 & 2.28 & $\begin{array}{l}7 \\
7\end{array}$ & $\begin{array}{r}21.9 \\
4\end{array}$ & $\begin{array}{l}8 \\
5\end{array}$ & $\begin{array}{r}24.2 \\
2\end{array}$ & 7 & $\begin{array}{r}4.2 \\
7\end{array}$ & $\begin{array}{l}4 \\
0\end{array}$ & $\begin{array}{r}24 . \\
39\end{array}$ & $\begin{array}{l}4 \\
7\end{array}$ & $\begin{array}{r}28.6 \\
6\end{array}$ & $\begin{array}{l}1 \\
5\end{array}$ & $\begin{array}{r}2.9 \\
1\end{array}$ & $\begin{array}{l}1 \\
1 \\
7\end{array}$ & $\begin{array}{r}22 . \\
72\end{array}$ & $\begin{array}{l}\mathbf{1} \\
\mathbf{3} \\
\mathbf{2}\end{array}$ & 26 \\
\hline 7. & $\begin{array}{l}20 \\
13\end{array}$ & 0 & 0.00 & $\begin{array}{l}1 \\
5\end{array}$ & 4.27 & $\begin{array}{l}1 \\
5\end{array}$ & 4.27 & 0 & $\begin{array}{r}0.0 \\
0\end{array}$ & 1 & $\begin{array}{r}0.6 \\
1\end{array}$ & 1 & 0.61 & 0 & $\begin{array}{r}0.0 \\
0\end{array}$ & $\begin{array}{l}1 \\
6\end{array}$ & $\begin{array}{r}3.1 \\
1\end{array}$ & $\begin{array}{l}1 \\
6\end{array}$ & 3 \\
\hline 8. & $\begin{array}{l}20 \\
14\end{array}$ & 1 & 0.28 & 2 & 0.57 & 3 & 0.85 & 1 & $\begin{array}{r}0.6 \\
1\end{array}$ & 1 & $\begin{array}{r}0.6 \\
1\end{array}$ & 2 & 1.22 & 2 & $\begin{array}{r}0.3 \\
9\end{array}$ & 3 & $\begin{array}{r}0.5 \\
8\end{array}$ & 5 & 1 \\
\hline & $\begin{array}{l}\text { To } \\
\text { tal }\end{array}$ & $\begin{array}{l}3 \\
5\end{array}$ & 9.97 & $\begin{array}{l}3 \\
1 \\
6\end{array}$ & $\begin{array}{r}90.0 \\
3\end{array}$ & $\begin{array}{l}3 \\
5 \\
1\end{array}$ & $\begin{array}{r}100 . \\
00\end{array}$ & $\begin{array}{l}2 \\
8\end{array}$ & $\begin{array}{r}17 . \\
07\end{array}$ & $\begin{array}{l}1 \\
3 \\
6\end{array}$ & $\begin{array}{r}82 . \\
93\end{array}$ & $\begin{array}{l}1 \\
6 \\
4\end{array}$ & $\begin{array}{r}100 . \\
00\end{array}$ & $\begin{array}{l}6 \\
3\end{array}$ & $\begin{array}{r}12 . \\
23\end{array}$ & $\begin{array}{l}4 \\
5 \\
2\end{array}$ & $\begin{array}{r}87 . \\
77\end{array}$ & $\begin{array}{l}\mathbf{5} \\
\mathbf{1} \\
\mathbf{5}\end{array}$ & $\begin{array}{r}100 . \\
00\end{array}$ \\
\hline
\end{tabular}

Source: Computed from Panchayats' data; Data presented in parentheses are percentage.

Another point to be noted here is that of the number of job cards in a family. All of the adult members in a family have the right to enroll themselves under MGNREGS and own a job card. 
International Journal of Trend in Scientific Research and Development (IJTSRD) ISSN: 2456-6470

\section{TABLE - 7 NUMBER OF JOB CARDS IN RESPONDENTS' FAMILY}

\begin{tabular}{|c|c|c|c|c|c|c|c|}
\hline \multirow{2}{*}{$\begin{array}{l}\text { S. } \\
\text { No. }\end{array}$} & \multirow[t]{2}{*}{ Number of Job Cards per family } & \multicolumn{2}{|c|}{ Seethaparpanallur } & \multicolumn{2}{|c|}{ Sivasailam } & \multicolumn{2}{|c|}{ Total } \\
\hline & & No. & per cent & No. & per cent & No. & per cent \\
\hline 1. & One Card holding family & 48 & 13.68 & 39 & 23.78 & 87 & 16.89 \\
\hline 2. & Two Cards holding family & 112 & 31.91 & 39 & 23.78 & 151 & 29.32 \\
\hline 3. & Three Cards holding family & 7 & 1.99 & 1 & 0.61 & 8 & 1.55 \\
\hline 4. & $\begin{array}{l}\text { Eligible, but not having more than one } \\
\text { Card holding family }\end{array}$ & 184 & 52.42 & 85 & 51.83 & 269 & 52.23 \\
\hline & Total & 351 & 100.00 & 164 & 100.00 & 515 & 100.00 \\
\hline
\end{tabular}

Source: Computed from field data; Data presented in parentheses are percentage.

Table -7 shows that 47.77 per cent of the total participants' families have enrolled all their adult members in the programme. Rest of the families, 52.23 per cent, have enrolled only one member and left out the rest of their adult members from this programme. It clearly indicates that the majority of the registered families have other opportunities of livelihood than this MGNREGS programme. This statement is supported by the following table (Table - 8):

\section{TABLE - 8 REASON FOR TAKING PART IN MGNREGS}

\begin{tabular}{|c|c|c|c|c|c|c|c|}
\hline \multirow{2}{*}{ S. No. } & \multirow{2}{*}{ Reason } & \multicolumn{2}{|c|}{ Seethaparpanallur } & \multicolumn{2}{|c|}{ Sivasailam } & \multicolumn{2}{|c|}{ Total } \\
\hline & & No. & per cent & No. & per cent & No. & per cent \\
\hline 1. & $\begin{array}{l}\text { Only one eligible person } \\
\text { available for this work }\end{array}$ & 11 & 3.13 & 7 & 4.27 & 18 & 3.50 \\
\hline 2. & Single person & 37 & 10.54 & 29 & 17.68 & 66 & 12.82 \\
\hline 3. & $\begin{array}{l}\text { Others are earning more from } \\
\text { other works }\end{array}$ & 260 & 74.07 & 79 & 48.17 & 339 & 65.83 \\
\hline 4. & Others are unable to do & 22 & 6.27 & 14 & 8.54 & 36 & 6.99 \\
\hline 5 . & $\begin{array}{l}\text { Each of the adult takes turn or } \\
\text { Person without job at that time } \\
\text { or Elderly Person }\end{array}$ & 21 & 5.98 & 35 & 21.34 & 56 & 10.87 \\
\hline & Total & 351 & 100.00 & 164 & 100.00 & 515 & 100.00 \\
\hline
\end{tabular}

Source: Computed from field data; Data presented in parentheses are percentage.

Table -8 clearly shows that each of other adult members in the family earn more than what the participant earns from MGNREGS. Therefore, there is a greater need to address this issue through educating the rural mass on the aim and goals of MGNREGS in order to avoid the resources.

\section{NEEDED AMENDMENTS REGISTRATION PROCESS}

A mass awareness campaign and education could be conducted using traditional and rural communication methods among the rural mass on the aim and goals of and procedure to take part in MGNREGS. It should be aimed at informing, educating and discussing with illiterate and less literate people in the communities.

IN $>$ Since most of the participants of MGNREGS are women, Women Self Help Groups could be approached and educated on the needed aspects. 
Education and guidance should be given to the needy person, who approaches for registering and obtaining job card.

$>$ The unutilised job cards could be recovered from the holders by informing them that this job card is only for MGNREGS purpose and they can retrieve it, when they are in such a need. This process will pacify the anxiety of the people and help them to understand what a real job card means. It may be a rectification process; but, still it will help the people in future to understand properly any such programme.

And also, this process will facilitate the people in the community to understand the aim, goals and functioning of the programme, which will enable them to be in support of the implementation of the programme - enhancing the rural livelihood.

\section{CONCLUSION}

Registration and obtaining job card are the key to take part in MGNREGS activities. The insufficient communication and understanding between the implementers and the beneficiaries made gap in this process, which had levied both the sides very much. People those who do not in need of this programme also registered and obtained job cards. They constitute about 50 per cent of the total job card holding families. They spent their money and time without purpose. It has led the administration of the government too spent time and money on this. It should be rectified at the earliest in order to pacify the anxiety of the people and correct the process in future. It will help the people in future to take little more effort for understanding such propgrammes. And also, it will facilitate the non-participants of the programme to be in support of enhancing the rural livelihood and rural livelihood options.

\section{REFERENCES}

1) Ashley, C., D. Start, \& R. Slater. 2003. Understanding livelihoods in rural India: Diversity, change and exclusion. Oversees Development Institute (ODI) Livelihoods Options Policy Guidance Sheets. ODI, London

2) Bernstein, H., B. Crow \& H. Johnson. 1992. Rural livelihoods: crises and responses, Oxford University Press, Oxford.
3) Brock, K. and N. Coulibaly. 1999. Sustainable rural livelihoods in Mali. IDS research report, 35. Brighton: IDS.

4) Disa Sjoblom and John Farrington (2008) Indian National Rural Employment Guarantee Act: Will it reduce poverty and boost economy? Oversees development institute

5) https://www.soas.ac.uk

6) http://www.livelihoodscentre.org

7) http://citeseerx.ist.psu.edu

8) http://www.nrega.nic.in

9) www.nrega.nic.in

10) NREGA operational guidelines $-2008,3^{\text {rd }}$ edition

11) http:/www.nrega.nic.in/netnrega/home.aspx

12) http:/www.policyproposalfor india.com

13) http://www.window2india.com (government's poverty alleviation programs: are they effective?)

14) htpp://www.livemint.com/2011/09/21191111/lessthan-9-households-could.htm/ NREGA 2005. 